\title{
Geopolymerization and Structure Formation in Alkali Activated Aluminosilicates with Different Crystallinity Degree
}

\author{
N. Kozhukhova ${ }^{1(\bowtie)}$, V. Strokova ${ }^{1}$, I. Zhernovsky ${ }^{1}$, and K. Sobolev ${ }^{2}$ \\ ${ }^{1}$ Belgorod State Technological University named after V.G. Shukhov, \\ Belgorod, Russia \\ kozhuhovanata@yandex.ru \\ ${ }^{2}$ University of Wisconsin-Milwaukee, Milwaukee, USA
}

\begin{abstract}
The work presents the results of grain-size analysis of alkaliactivated aluminosilicate suspensions with different crystallinity degree. It is found that the crystallinity degree of aluminosilicate is inversely proportional to its solvability in strong alkaline substance. The mechanism of geopolymeric system formation during the geopolymerization process has been suggested.
\end{abstract}

Keywords: Aluminosilicates - Crystallinity degree - Structure formation • Geopolymerization

\section{Introduction}

The application of colloid and nano-sized silicate and aluminosilicate components for the synthesis of effective binding systems is one of the most attractive directions in the science of construction materials (Vivian et al. 2017; Dmitrieva et al. 2018; Sobolev 2016).

The earlier studies (Shekhovtsova et al. 2018; Galindo Izquierdo et al. 2009) discussed various factors influencing the ability of alkali activated cements to form the aluminosilicate structures from the anthropogenic aluminosilicates, in particular fly-ash (Kozhukhova et al. 2018; Wang et al. 2018).

\section{Materials and Methods}

To estimate the viability of the research hypothesis three types of natural aluminosilicates with a different crystallinity degree were used:

- Obsidian - effusive rock of an acidic composition and amorphous structure;

- Pearlite - effusive rock of an acidic composition and crypto-crystalline structure;

- Crouan - intrusive compound acidic rock with a hollow crystalline structure.

To prepare alkaline silicate suspensions the equal volumes (50 g) corresponding to each sample of milled aluminosilicate material were placed into glass bottles and mixed with $50 \% \mathrm{NaOH}$ water solution. 
These suspensions were mixed for three days (72 h) using a LS-110 mixing device. The specific surface and the average size of grains of aluminosilicate powders was performed using a laser analyzer ANALYSETTE 22 NanoTec plus.

\section{Results and Discussions}

This report is based on the hypothesis that during the alkaline activation of aluminosilicate particles the dissolving process is gradual, starting with the dissolution of surface layers. As the result, the alkali aluminosilicate gel is formed which acts as a binding base for further geopolymerization. At the same time, the aluminosilicate component crystallinity degree influences its solubility in the alkaline medium.

To test the research hypothesis the average size of the aluminosilicate particles average size was determined as well as the specific area in the initial condition and also after the alkaline activation (Table 1).

Table 1. The particle size and specific area of alumosilicate powders after the alkaline activation

\begin{tabular}{l|l|l|l|l|l|l|l}
\hline № & $\begin{array}{l}\text { Aluminosilicate } \\
\text { type }\end{array}$ & \multicolumn{2}{|l|}{$\begin{array}{l}\text { Average particle size, } \\
\mu \mathrm{m}\end{array}$} & $\begin{array}{l}\text { Change, } \\
\%\end{array}$ & \multicolumn{2}{l}{ Specific area, $\mathrm{m}^{2} / \mathrm{kg}$} & $\begin{array}{l}\text { Change, } \\
\%\end{array}$ \\
\cline { 3 - 7 } & $\begin{array}{l}\text { Before } \\
\text { activation }\end{array}$ & $\begin{array}{l}\text { After } \\
\text { activation }\end{array}$ & & $\begin{array}{l}\text { Before } \\
\text { activation }\end{array}$ & $\begin{array}{l}\text { After } \\
\text { activation }\end{array}$ & \\
\hline 1 & Crouan & 11 & 9 & -16 & 910 & 1003 & 10 \\
\hline 2 & Perlite & 11 & 14 & 21 & 838 & 774 & -7 \\
\hline 3 & Obsidian & 14 & 17 & 23 & 785 & 642 & -18 \\
\hline
\end{tabular}

The results of grain size analysis for crouan after the alkaline activation prove that the average particle size is reduced relative to the particle size before activation. It may be caused by crouan grains subsolution resulting in the reduction of the particle size.

At the same time in the alkaline activated suspensions of perlite and obsidian there is a tendency of particle size increase in comparison with those before activation.

Hence, for crouan there is an increase of the specific area of the solid phase after the activation and a decrease of average particle size.

In case of perlite and mostly obsidian, the alkaline activation has a reverse effect: the specific area decreases and the average particle size increases (Fig. 1).

The received data of the grain size analysis suggested a scheme of aluminosilicate structure formation that occurs during the geopolimerization. This scheme includes two simultaneous processes: the dissolution of the aluminosilicate component and the formation of the alkali aluminosilicate gel, which is the chemical interaction of alkali aluminosilicate gel with unreacted grains. The chemical interaction causes the formation of a «gel layer - unreacted grain» in investigated system. 


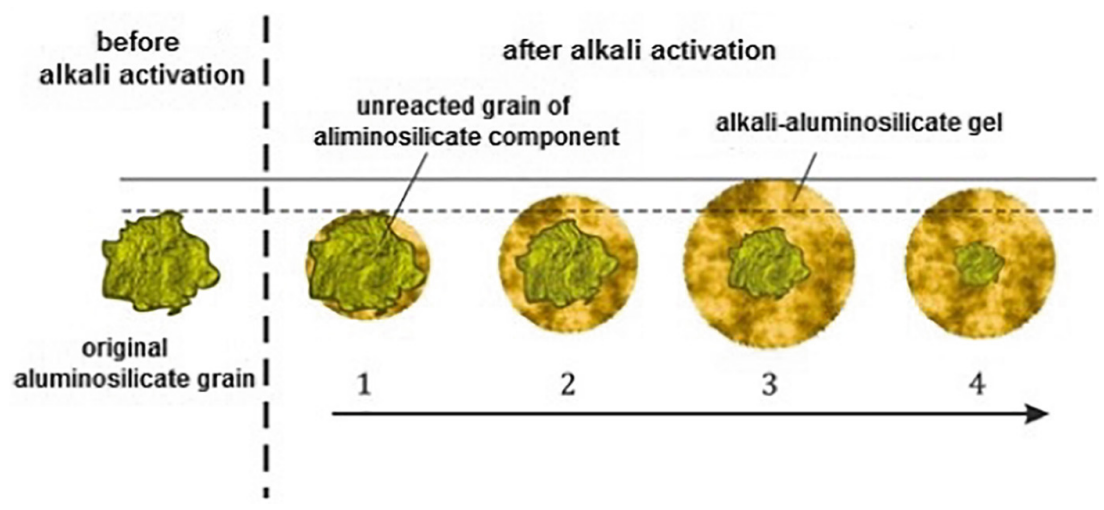

Fig. 1. The structure formation mechanism in the system "gel layer - unreacted grain of aluminosilicate component" during the alkali activation.

The lower aluminosilicate crystallinity degree results in a high intensity of the dissolution of aluminosilicate particles and a thicker surface gel layer based on the newly formed compound.

\section{Conclusion}

The crystallinity degree of aluminosilicates is inversely proportional to the reactivity in alkali systems, which is controlled by the solubility degree in highly alkali medium. Based on this observation, it was suggested that the geopolimerization scheme in the system «gel layer - unreacted grain of aluminosilicate component» occurs during the alkaline activation.

Acknowledgements. The work has been fulfilled within the project Federal Target Program of Research and Development on "Priority Development Fields of science and technology sector in Russia for 2014-2020", unique project number is RFMEFI58317X0063.

\section{References}

Dmitrieva TV, Strokova VV, Bezrodnykh AA (2018) Influence of the genetic features of soils on the properties of soil-concretes on their basis. Constr Mater Products 1:69-77

Galindo Izquierdo M, Querol X, Davidovits J, Antenucci D, Nugteren HW, Fernández-Pereira C (2009) Coal fly ash-slag-based geopolymers: microstructure and metal leaching. J Hazard Mater 166(1):561-566

Kozhukhova NI, Zhernovsky IV, Sobolev KG (2018) Effect of variations in vitreous phase of low-calcium aluminosilicates on strength properties of geopolymer systems. Bull BSTU named after V.G. Shukhov 3:5-12

Shekhovtsova J, Zhernovsky I, Kovtun M, Kozhukhova N, Zhernovskaya I, Kearsley PE (2018) Estimation of fly ash reactivity for use in alkali-activated cements - a step towards sustainable building material and waste utilization. J Cleaner Prod 178:22-33 
Sobolev K (2016) Modern developments related to nanotechnology and nanoengineering of concrete. Front Struct Civil Eng 10(2):131-141

Vivian F-I, Pradoto R GK, Moini M, Kozhukhova M, Potapov V, Sobolev K (2017) The effect of $\mathrm{SiO}_{2}$ nanoparticles derived from hydrothermal solutions on the performance of portland cement based materials. Front Struct Civil Eng 11(4):436-445

Wang YS, Provis JL, Dai JG (2018) Role of soluble aluminum species in the activating solution for synthesis of silico-aluminophosphate geopolymers. Cement Concrete Compos 93:186195

Open Access This chapter is licensed under the terms of the Creative Commons Attribution 4.0 International License (http://creativecommons.org/licenses/by/4.0/), which permits use, sharing, adaptation, distribution and reproduction in any medium or format, as long as you give appropriate credit to the original author(s) and the source, provide a link to the Creative Commons license and indicate if changes were made.

The images or other third party material in this chapter are included in the chapter's Creative Commons license, unless indicated otherwise in a credit line to the material. If material is not included in the chapter's Creative Commons license and your intended use is not permitted by statutory regulation or exceeds the permitted use, you will need to obtain permission directly from the copyright holder. 